\title{
Conditions associated with adherence to HIV post-sexual exposure prophylaxis
}

\author{
Condições associadas à adesão à profilaxia pós-exposição sexual ao HIV \\ Condiciones asociadas con la adhesión a la profilaxis post-exposición al VIH
}

How to cite this article:

Silva MMS, Nichiata LYI, Simão NS, Silveira RA. Conditions associated with adherence to HIV post-sexual exposure prophylaxis. Rev Esc Enferm USP. 2021;55:e03699. doi: https://doi.org/10.1590/S1980-220X2019028403699

\section{Marcos Morais Santos Silva ${ }^{1}$ \\ Lucia Yazuko Izumi Nichiata² \\ Nathália Santana Simão ${ }^{1}$ \\ Regis Alves da Silveira ${ }^{3}$}

1 Universidade de São Paulo, Escola de Enfermagem, Programa de Pós-Graduação em Enfermagem, São Paulo, SP, Brazil.

${ }^{2}$ Universidade de São Paulo, Escola de Enfermagem, Departamento de Enfermagem em Saúde Coletiva, São Paulo, SP, Brazil.

3 Aids Healthcare Foundation,

São Paulo, SP, Brazil.

\begin{abstract}
Objective: To analyze conditions which interfere with adherence to HIV post-sexual exposure prophylaxis. Method: Cross-sectional study conducted in two health care services specializing in HIV/AIDS in São Paulo city. Interviewees included men and women who were eighteen or older, sought care due to consensual sexual relation, and had a recommendation for prophylaxis. The questionnaires which compose the social reproduction index and adherence to prophylaxis were used as parameters. Nonparametric Kruskal-Wallis and Mann-Whitney tests and summation of the employed instrument through programs Excel $^{\circledR}$ and Statistical Package for the Social Sciences ${ }^{\circledR}$ were performed. Ethical principles have been respected. Results: Forty-nine users have been identified; their mean age was 34.7 and they were predominantly men (95.9\%). Out of these, $83.6 \%$ were men who have sex with men. The conditions which correlated with adherence $(p<0.05)$ were taking post-sexual exposure prophylaxis prior to that appointment and continuing to take the medication. Conclusion: Health professionals are responsible for establishing rapport with service users, especially during the first appointment, to contribute to adherence interventions plans.
\end{abstract}

\section{DESCRIPTORS}

HIV; Medication Adherence; Post-Exposure Prophylaxis; Public Health Nursing. 


\section{INTRODUCTION}

From the onset of the AIDS epidemic, in the 1980's, to 2018 , around 74.9 million people are estimated to have been infected with HIV, with 32 million deaths from an AIDS-related complication ${ }^{(1-3)}$. As a response to the impacts of HIV, treatment and control efforts have been intensifying to minimize damage from the evolution of this disease until an AIDS clinical condition is established ${ }^{(1-5)}$.

Treatment for HIV has improved in various ways with the implementation of antiretroviral therapy (ART) from the 1990's to 2000. It started a new phase in disease control, ensuring improvements in the quality of life of people living with HIV. Consequences of ART include stronger infection control through a reduction in hospitalization and mortality rate, in addition to immune system improvements that decreased infections with other opportunistic diseases ${ }^{(3-5)}$.

Advancements towards reduction of new HIV infection cases are related to technological developments in prevention related to both diagnosis and treatment. Funding, improvements, and continuation of educational prevention programs add up to bring positive outcomes for fighting HIV. Changes in the preventive and responsibility discourses aimed at a specific population have enabled work focused on recognizing vulnerabilities in different social contexts which directly affect individuals, contributing to the development of new strategies for fighting this disease ${ }^{(2-7)}$.

As an attempt to fill gaps to prevent and reduce the number of HIV infections, a combined prevention strategy was developed, increasing the number of options by combining one or more preventive strategies ${ }^{(1-2)}$. These methods include behavioral interventions, such as incentives to changes in sexual practices, aimed at reducing damage by employing preventive methods; structural interventions, such as educational campaigns and the fight for human rights; and biomedical interventions, which consist of offering penile or vaginal condoms, pre-exposure prophylaxis (PrEP), and post-exposure prophylaxis (PEP) $)^{(2-7)}$.

This study concentrates on $\mathrm{PEP}^{(4)}$, which consists of the use of antiretrovirals (ARV) with a combination of two or three medications for 28 days to be started in up to 72 hours after virus exposure to avoid its reproduction and, consequently, infection transmission, guaranteeing an improved prophylaxis efficacy ${ }^{(4-6)}$.

In Brazil, PEP has been available in the health services network since 1999 and was initially indicated as a form of prevention for health professionals exposed to direct contact with body fluids through piercing and cutting material ${ }^{(2-4)}$. From 2010 onwards it became a broader therapeutic intervention: in addition to its role in care for health professionals, it is directed at people who had unprotected sexual exposure, which characterizes thus sexual PEP. Prophylaxis, which is thoroughly available via Unified Health System (Sistema Unico de Saúde - SUS), represents a public health measure for preventing HIV infections ${ }^{(3-4)}$.

Upon consultation of the literature to identify findings on PEP, few Brazilian studies were found to explore its mechanism of action, the treatment process and, more specifically, the conditions surrounding the start of ARV use. Prophylaxis adherence interferes directly with its efficacy, whose possible barriers are sociodemographic characteristics, such as employment and residency status, associated to social reproduction, lack of information, inappropriate professional care, distance from health services, and difficulty in using the medication ${ }^{(5-9)}$. By understanding the conditions associated to PEP adherence, it is possible to contribute with improvements in public policies, making them more effective against the HIV epidemic, as well as to upgrade health assistance, involving health professionals - specially nursing personnel - and service users ${ }^{(4,6-7)}$.

Considering these aspects, it is necessary to focus on the magnitude of the epidemic in São Paulo city, where HIV/ AIDS was first identified in Brazil: between 1980 and 2018, 99,905 cases of AIDS were identified in São Paulo ${ }^{(3)}$. From this perspective, this study aimed at analyzing conditions which interfere with the adherence to sexual HIV PEP by health service users in São Paulo city, Brazil.

\section{METHOD}

\section{Design OF STUdY}

This is a cross-sectional study.

Adherence was employed as a conceptual reference ${ }^{(8-9)}$. This was understood as the sum of conditions associated to individuals' development in society, not limited to the outcomes of singular attitudes or behavior but considering also the reality surrounding their insertion in the social group and their life habits.

\section{LOCAL}

Although access to PEP is provided also in health services, such as first-aid posts in hospitals, reference centers, and testing and counselling centers ${ }^{(3-4)}$, the present study was conducted in two HIV/AIDS specialized care services (SCS) in the Center and Southeast regions of the city which offer $\mathrm{PEP}$ routinely. These host actions for care, prevention, and treatment of people living with HIV/AIDS which are laid out in São Paulo's Municipal Program for STI/AIDS ${ }^{(3-4)}$.

Exams conducted in these services include rapid tests, conventional exams - in which the collected material is sent to a clinical laboratory for analysis and HIV detection - and tests for syphilis and hepatitis B and C. Their users can also collect material for the prevention of sexually transmitted infections (STI), such as male and female condoms, in addition to lubricant gel. First care is provided to users by professionals responsible for the reception; users are then forwarded to the physician and other professionals for follow-up. Specifically for the process of orientation and start of sexual PEP, a mean six to eight people/day are received in the central region service, and three to four are received in the southeast region service. The regions in which health services are located have a high AIDS detection rate (DR): southeast (35.5 per 100,000 inhabitants) and center (112 per 100,000 inhabitants); República - where one of the analyzed health services is located - is the neighborhood with the highest DR: 132.4 per 100,000 inhabitants. 


\section{SELECTION CRITERIA}

The established inclusion criteria were men and women older than 18 who sought the service due to consented sexual relation, had an indication of post-exposure chemoprophylaxis according to clinical protocol and the therapeutic directives for $\mathrm{PEP}^{(4)}$, and returned after 30 days for the first appointment after finishing the ARV. The exclusion criterion was indication of PEP for occupational exposure and situations involving sexual violence. The sample was by convenience and the final sample of interviewees corresponded to the users who met the research's inclusion criteria and accepted to participate in the period proposed for data collection; this amounted to 49 users.

\section{Data COllection}

The data were collected between July 2017 and February 2018. The users were invited to participate in this research after being approached by the researcher (after the followup visit to the health professional). Users were ensured to be in a private environment; the answers were registered by the researcher.

The interviews were conducted with two instruments. The first was the social reproduction index $(\mathrm{SRI})^{(10)}$, employed to obtain data for socioeconomic characterization. This instrument was a means to understand the dimension of production (work card registration, years of education, occupational qualification, conduction of activities, professional training course) and consumption (home ownership or lack thereof, access to public water, electricity, and sewage services, payment of Urban Building and Land Tax (Imposto Predial e Territorial Urbano - IPTU), religious practice, and leisure activities). These dimensions are significant to identify social groups $(\mathrm{G})$, which were divided into four categories: GI, GII, GIII, and GIV. The categories GI and GII imply better life conditions and access to health services; GIII and GIV indicate characteristics of social vulnerability ${ }^{(10)}$. Differences in characteristics among these groups may interfere with adherence ${ }^{(9)}$.

The second instrument is inspired by the study Cuestionario para la Evaluación de la Adhesión al Tratamiento Antiretroviral (CEAT-VIH), in a Brazilian adaptation ${ }^{(11)}$. This instrument tackles issues which may help understand the easiness and difficulties of PEP adherence, such as whether users employed some strategy to remember and/or facilitate medication use, if there was some difficulty taking medication or whether they presented some adverse reaction ${ }^{(11)}$. These questions are related to the health process which, depending on the users' understanding, may make them more active or more passive regarding medication adherence ${ }^{(9)}$. In this adaptation, terms associated to HIV were changed to cover PEP. Two of the twenty questions had to be removed because they were directed at the process of treating people living with HIV and were unapplicable to people using PEP.

The score of the original CEAT-VIH ranges from 17 to 89: seventeen questions have a score between 1 and 5 , one has a score between 0 and 2, and two have a score between 0 and $1^{(11)}$. In the present study, 18 questions were used. One of them, which had a score between 0 and 1 in the original instrument, was adapted to have a score between 1 and 5, standardizing the values attributed to the variables. Finally, the instrument included 18 questions with a score between 1 and 5. The total score obtained from the sum of all the items ranged thus from 18 (minimum) to 90 (maximum).

Since there is yet no protocol to define whether a user has adhered to PEP, this study proposes that adherence be evaluated by a score achieved in the adherence scale, as established in the original instrument ${ }^{(11)}$. In the original questionnaire, Pearson correlation was performed to test the hypothesis that the higher the adherence, the lower the viral load would be. The results showed a significant inverse correlation. In the variance analysis (ANOVA) of a factor to classify the sample into three groups through adherence degree, the categories low/insufficient adherence $(\leq 74)$, good/appropriate adherence (75 to 79), and strict adherence $(\geq 80)$ were established from the score. For this study, due to sample size, classification into two groups was opted for. Thus, adherence was admitted as low/insufficient (score $\leq 74$ ) or good/appropriate (score $\geq 75$ ).

\section{Data TREATMENT AND ANALYSIS}

Programs used for statistical analysis included Excel ${ }^{\circledR}$, for the elaboration of a database, and Statistical Package for the Social Sciences ${ }^{\circledR}$ (SPSS) for the analysis itself. In the case of sociodemographic, knowledge and PEP usage variables, non-parametric tests Kruskal-Wallis and Mann-Whitney were performed, with the summation of the values of the employed instrument, applying statistical associations among the obtained values.

\section{ETHICAL ASPECTS}

The research project was approved by Universidade de São Paulo's Nursing School Research Ethics Committee in Opinion n. 2.070.719, dated May 18, 2017, and, after an amendment, in Opinion n. 2.240.516, dated August 25, 2017. It was also approved by the São Paulo City Hall in Opinion n. 2.077.096, dated May 23, 2017 and, after an amendment, in Opinion n. 2.315.681, dated October 5, 2017, in accordance with the established in Resolution n. 466/12, by the National Health Council. All participants signed the Informed Consent Form (ICF) and all their questions were answered.

\section{RESULTS}

The interviewees comprised 49 SCS users. These were predominantly men $(95.9 \%)$ who identified with the male gender (93.9\%) and were white skinned (49.0\%), single $(85.7 \%)$, with a mean age of 34.7 years, standard deviation (SD) of 10.6 and a median of 34 years (minimum 19 and maximum 68 years), 8 years of education or more $(93.9 \%)$, and with no religion (40.8\%). In the social group distribution, GI (53.1\%) prevailed, followed by GII (30.6\%).

Out of the total, $83.6 \%$ are men who have sex with men (MSM) and $12.3 \%$ are men who have relations only with women. Regarding PEP, 75.5\% had prior knowledge of it and $44.9 \%$ had used it before the new indication (Table 1 ). 
Table 1 - User distribution according to sexual relation, knowledge, and use of PEP - São Paulo, Brazil, 2019.

\begin{tabular}{lcc}
\hline \multirow{2}{*}{ Variable } & \multicolumn{2}{c}{ Total } \\
\cline { 2 - 3 } & $\mathrm{N}$ & $\%$ \\
\hline Sexual relation & 30 & 61.2 \\
Men who have sex only with men & 11 & 22.4 \\
Men who have sex with both men and women & 6 & 12.3 \\
Men who have sex only with women & 2 & 4.1 \\
Women who have sex only with men & & \\
\hline Had prior knowledge of PEP & 37 & 75.5 \\
Yes & 12 & 24.5 \\
No & & \\
\hline Had used PEP previously & 22 & 44.9 \\
Yes & 27 & 55.1 \\
No &
\end{tabular}

Regarding user distribution per sociodemographic variables and their correlation with adherence, being married or in a domestic partnership presented a mean correlation of 77.7 and 77.0, respectively. Black skin presented a mean of 74.2 ( $\mathrm{SD} \pm 7.9$ ). Concerning religion, not having any presented a mean $78.0(\mathrm{SD} \pm 5.3)$ (Table 2).

In relation to the adherence scale of the total of users, there was a 49 to 88 score variation, with a mean 75.7 (SD \pm 7.4 ). In addition, low/insufficient adherence (score $\leq 74$ ) was presented by Catholics (72.4\%), Evangelicals (72.2\%), those in GIV (61.0\%), and those who had used PEP before the new indication (73.1\%), whether they stopped taking the medication or not. Statistically significant variables for conditions which interfere with PEP adherence included having used PEP previously and having stopped to take the medication $(p<0.05)$ (Table 2).

Table 2 - User distribution per sociodemographic variables and their correlation with adherence - São Paulo, SP, Brazil, 2019.

\begin{tabular}{|c|c|c|c|c|}
\hline \multirow{2}{*}{ Variable } & \multicolumn{4}{|c|}{ Adherence score* } \\
\hline & Minimum & Mean (SD) & Maximum & $p^{* * *}$ \\
\hline \multicolumn{5}{|l|}{ Marital status } \\
\hline Single & 49 & $75.2(7.8)$ & 88 & \multirow{4}{*}{0.510} \\
\hline Married & 76 & $77.7(2.8)$ & 82 & \\
\hline Divorced & 77 & $77.0^{* *}$ & 77 & \\
\hline Domestic partnership & 85 & $85.0^{* *}$ & 85 & \\
\hline \multicolumn{5}{|l|}{ Skin color } \\
\hline White & 49 & $76.8(7.8)$ & 88 & \multirow{4}{*}{0.799} \\
\hline Brown & 58 & $74.7(7.1)$ & 86 & \\
\hline Black & 61 & $74.2(7.9)$ & 84 & \\
\hline Asian & 76 & $76.0^{* *}$ & 76 & \\
\hline \multicolumn{5}{|l|}{ Years of education } \\
\hline $4-7$ & 76 & $78.0(2.6)$ & 81 & \multirow{2}{*}{0.586} \\
\hline$\geq 8$ & 49 & $75.5(7.6)$ & 88 & \\
\hline \multicolumn{5}{|l|}{ Religion } \\
\hline Catholic & 49 & $72.4(10.1)$ & 83 & \multirow{4}{*}{0.544} \\
\hline Evangelical & 58 & $72.2(9.5)$ & 78 & \\
\hline Other & 65 & $76.0(6.5)$ & 86 & \\
\hline None & 68 & $78.0(5.3)$ & 88 & \\
\hline
\end{tabular}

\begin{tabular}{lcccc}
\hline \multirow{2}{*}{$\begin{array}{l}\text { V.continuation } \\
\text { Variable }\end{array}$} & \multicolumn{4}{c}{ Adherence score* } \\
\cline { 2 - 5 } & Minimum & Mean (SD) & Maximum & $p^{* * *}$ \\
\hline Social group & 49 & $75.6(7.8)$ & 86 & \\
GI & 58 & $76.5(7.9)$ & 88 & \\
GII & 73 & $76.6(2.0)$ & 78 & 0.464 \\
GIII & 61 & $61.0^{* *}$ & 61 & \\
GIV & 58 & $73.1(6.4)$ & 86 & 0.007 \\
\hline Have used PEP previously & & & & \\
Yes & 49 & $77.8(7.6)$ & 88 & \\
No & 58 & $58.6(8.4)$ & 69 & 0.043 \\
\hline Have stopped taking the medication & & & \\
Yes & 46 & $67.0(3.8)$ & 74 & \\
No & 57 &
\end{tabular}

* The values of this instrument range from 18 to 90 .

**Standard deviation does not apply (size 1 sample).

***Tests performed: Wilcoxon-Mann-Whitney (variables: gender, years of education, previous use of PEP, and suspension of medication use) and Kruskal-Wallis (variables: marital status, skin color, religion, social group). The values $p<0.05$ were statistically significant.

\section{DISCUSSION}

In this study, males were predominant in relation to females in seeking sexual PEP; this is corroborated by findings of studies from other countries ${ }^{(12-22)}$. This research has also found a higher percentage of MSM who seek sexual PEP, converging with other studies ${ }^{(12,15-17)}$.

In the historical context of HIV/AIDS, men, and most specifically MSM, were socially associated to the stigma attributed to this disease and had difficulties in adhering to preventive measures ${ }^{(4,18)}$, which characterizes a condition of vulnerability to HIV infection. When it comes to public policies, MSM represent a key population to whom preventive actions for this disease are directed. However, such actions are currently insufficient, considering that the incidence of infections has been increasing in many countries ${ }^{(11-16)}$. In a study performed in 12 Brazilian capitals, in which 4,176 MSM were interviewed, $18.4 \%$ of them were found to be infected with HIV in 2016 - i.e., almost 1 in every 5 MSM lived with HIV, which indicates flaws in adherence to preventive methods ${ }^{(19)}$.

Adherence to prophylaxis is influenced by different conditions. The studies emphasize that favorable conditions for the adherence to PEP include the types of ARV used, little or no side-effect, age of majority, education level, being male, rapport between patient and health professionals, having received appropriate orientation, and being received in a discreet environment for counselling in the first appointment and during returns ${ }^{(6,12-15,21-23)}$.

In this study, $93.9 \%$ of users reported being men. The literature points out that there are differences in the access of women to services directed at HIV/AIDS, when compared to men $^{(14,18,20)}$. The number of women infected with HIV has increased between 2006 and 2016 in Brazil, especially in the age ranges between 15 and 19 years and older than 60 years $^{(4)}$, which may indicate their difficulty of access to preventive measures, making them more vulnerable to $S T I^{(16)}$. In this sense, there is a need for exploring the specificities of these populational segments, considering their differences 
and singularities in fighting HIV, especially in comparison to the male population ${ }^{(16,18-20)}$.

Concerning the use of PEP, users with no previous experience presented a higher mean adherence $(77.8 ; \pm 7.6$; $p=0.007)$, classified as good/appropriate, when compared to people who were repeating prophylaxis $(73.1 ; \pm 6.4)$. Continuing with medication was also significant for the adherence $(p=0.043)$ and proper observation of PEP. These results are similar to those of a different study ${ }^{(13)}$. However, a study shows that, for a better adherence to prophylaxis, it does not suffice to provide medication to the users and schedule them to return 30 days later with no direct follow-up of the appropriate use of PEP. The importance of improving communication strategies and following these users through the duration of prophylaxis is emphasized ${ }^{(24-28)}$.

Users who were performing PEP for the second time or more presented an inferior adherence to prophylaxis compared to those who had been taking it for the first time. Given the susceptibility to the risks of HIV infection, it is valid that professionals evaluate the needs of these users to understand the reasons for their unprotected sexual relations, evaluating the possibility of planning an alternative prevention with the use of PrEP, since this strategy would be beneficial and frequent use of PEP would be avoided ${ }^{(13)}$. A study conducted in Israel found a rate of adherence to PEP of 91\%; the reasons included detailed explanations on the importance of adherence, the use of few medications (only once a day), support measures in case of side-effects, and professional mental health support ${ }^{(28)}$. A combination of prophylactic interventions for the reduction of risks was shown to be more favorable for users than PEP alone ${ }^{(13,28)}$.

The studies point that factors which tend to disfavor PEP adherence are being an immigrant, having no healthcare plan, having a common cold, having difficulty to swallow the ARV, taking a daily dose following a fixed schedule, suffering with side-effects, having other STI, and recurrent exposure to unprotected sexual intercourse. This demonstrates thus that, even when users returned to health services for followup, PEP was not necessarily adhered to and the reduction in adherence is related not only to the ARV, but also to conditioning factors which determine the use of medication and the proper follow-up of prophylaxis by users ${ }^{(12-15,22,26)}$.

When analyzing the users' previous knowledge of PEP, a percentage of $24.5 \%$ was noticed not to understand prophylaxis. A study has shown that PEP still faces challenges, since almost two thirds of people ignore prophylaxis and those who affirm to know it do not have enough information on its function and how it should be used ${ }^{(21)}$. A study conducted in the United States has shown that some health professionals are unaware of this prophylaxis method and emphasizes that $39.3 \%$ of clinical physicians affirmed to have never prescribed PEP due to lack of knowledge on its function and its benefits to users ${ }^{(22)}$.

Concerning sociodemographic profile, white-skinned users who had eight or more years of education were predominant. Social groups I and II amounted to $83.2 \%$ of the interviewees, showing that most were in good life conditions per the dimension of production and consumption analyzed with $\mathrm{SRI}^{(10)}$. This population profile is observed in São Paulo state and in studies conducted in developed countries ${ }^{(12-13)}$. Population in worse life conditions possibly simply do not visit health services, since the increase of new HIV infection cases in Brazil is identified predominantly in brown and black, low-income, and low-education populations, especially when considering the states in the North and Northeast regions, indicating a difficulty of access to preventive and prophylactic methods for these individuals ${ }^{(2-4)}$.

Given the data found, it is important to consider economic differences, health public policies, and care provided in the different regions of Brazil, which reflect the barriers in access to preventive methods, affecting directly the most vulnerable social groups ${ }^{(4-7,20)}$ and, thus, adherence to PEP. A study conducted in 2013 has shown that South and Southwest Brazil offered better conditions for access to health services to the populations ${ }^{(23)}$; even so, these are exactly the areas whose municipalities have the highest rates of AIDS incidence, which highlights the need for considering expanding investment to enhance SUS and policies for fighting the epidemic. The state of São Paulo, a pioneer in establishing policies to fight STI, and especially HIV/ $\mathrm{AIDS}^{(24)}$, has been promoting the decentralization of actions to municipalities, which enables advances in SUS structure and is reflected in better access to health services ${ }^{(25)}$.

When analyzing the scores, being a Catholic or Evangelical, belonging to GIV, having used PEP previously, and having stopped taking the medication or not emerged as conditions of low/inappropriate adherence; however, when statistical associations were calculated, these variables were not significant. The variables marital status, skin color, and education were also not statistically significant.

The lack of statistical association for variables of social group and education diverges from what is observed in other studies, in which adherence was directly associated to groups with higher education, better social conditions, and access to health services, such as insurance, health plans, and specialized care ${ }^{(14,26-27)}$. This study presented a homogenous sample which had 8 years of education or more (93\%); also, GI and GII concentrated $83.2 \%$ of interviewees, which may have reflected in the result of the statistical analysis. At the same time, socially vulnerable individuals are possibly not accessing health services to use PEP, as previously presented.

According to authors, understanding the concept of adherence involves three independent planes: the way individuals understand the health-disease process and whether they act actively or passively in self-care; insertion in society, which determines the potential for fighting life deterioration, directly associated to financial conditions; and the organization of work processes, i.e., the means that an individual has to earn financial income ${ }^{(8,9)}$. In this perspective, adherence to PEP is recognized to involve conditions that are beyond a single user's will, for this is related to the how users understand the health-disease process, how they perform self-care, and what is their social insertion and their life habits, in addition to easiness or difficulty in accessing health services, considering also how policies for fighting HIV are developed and operated in that individual's reality ${ }^{(9-11)}$. 
After comprehending the conditions associated to adherence to PEP, it is possible to understand that the approach used in user care should be individualized; also, the construction of the care plan and follow-up should include and consider integral individual care, meeting its health demands ${ }^{(27-29)}$. Also, the rapport with users is fundamental for proper follow-up of PEP, especially for nursing professionals, who often make the first approach and the reception ${ }^{(26-30)}$.

This study had limitations which must be taken into account: only two SCS in two regions of São Paulo city, located close to the Center, were considered; whose results may not reflect the reality of different locations and profiles of users of other health services, as well as general conditions which interfere in the adherence to sexual HIV PEP. Also, only users who returned for the appointment 30 days after starting prophylaxis were investigated; users who started PEP and did not come to the service in the return date were not identified. Thus, verifying whether these users took ARV for the indicated time was impossible.

In addition to these aspects, the fact that changes were made to the original CEAT-VIH must be considered, since this instrument is applied to people diagnosed with HIV and their questions are targeted at following improvements in the users' health status from the rapport established with the service, observance of ART, reduction of viral load, and increase in cells which constitute the immune system. These characteristics do not correspond to the population analyzed in this study, which used ARV for only 28 days as a prophylactic measure. An additional limitation is related to the small number of investigated users, i.e., $n=49$.

\section{CONCLUSION}

The variables which had significant statistical associations as conditions for adherence to PEP were not having used PEP previously and not having forgotten to take the medication. Factors that may contribute to non-adherence include being a Catholic or Evangelical, belonging to an economically disfavored social group, and having used PEP more than once.

Forgetting to take medication is an important aspect to be explored by SCS to elaborate strategies which enable the articulation between service and user, creating an open channel of communication for users during the prophylaxis period. Leaving users unfollowed for the 28 days of ART gives ground for the non-observance of PEP.

Services must establish a mechanism of active search for users who do not go to scheduled follow-up visits. Also, health professionals are responsible for recognizing the profile of their users and the conditions which involve adherence to PEP or lack thereof to contribute to plans for interventions to be implemented, ensuring that care is tailored to each service user and aiming at the success of the proposed prophylaxis.

Studies that monitor health service users throughout PEP use and follow-up are necessary to increase understanding of this process, which ranges from the initial orientation to the end of follow-up visits. Attention would thus be paid to the reasons for the lack of appropriate use of ARV, nonattendance of appointments and, consequently, a lack of adherence to the prophylaxis.

\section{RESUMO}

Objetivo: Analisar condições que interferem na adesão à profilaxia pós-exposição sexual ao HIV. Método: Estudo de corte transversal, realizado em dois serviços de assistência especializada em HIV/aids no município de São Paulo. Foram entrevistados homens e mulheres maiores de 18 anos que procuraram atendimento por motivo de relação sexual consentida com indicação de profilaxia. Foram usados como parâmetros os questionários que compõem o índice de reprodução social e a adesão à profilaxia. Realizaram-se testes não paramétricos de Kruskal-Wallis e Mann-Whitney e análises somatórias do instrumento utilizado por meio dos programas Excel ${ }^{\circledR}$ e Statistical Package for the Social Sciences ${ }^{\circledR}$. Os preceitos éticos foram respeitados. Resultados: Foram detectados 49 usuários, com média de idade de 34,7 anos e predomínio de homens (95,9\%). Do total, 83,6\% eram homens que se relacionam sexualmente com homens. As condições que tiveram correlação com a adesão $(p<0,05)$ foram uso de profilaxia pós-exposição sexual anterior a esse atendimento e prosseguimento da ingestão dos medicamentos. Conclusão: Compete aos profissionais de saúde estabelecer o vínculo com o usuário do serviço, principalmente no primeiro atendimento, de modo a contribuir para o planejamento das intervenções para a adesão.

\section{DESCRITORES}

HIV; Adesão à Medicação; Profilaxia Pós-Exposição; Enfermagem em Saúde Pública.

\section{RESUMEN}

Objetivo: Analizar las condiciones que interfieren con la adherencia a la profilaxis post-exposición al VIH. Método: Estudio transversal, realizado en dos servicios especializados en VIH/sida en la ciudad de São Paulo. Se entrevistaron hombres y mujeres mayores de 18 años que buscaron atención por relaciones sexuales consentidas con indicación de profilaxis. Se utilizaron como parámetros los cuestionarios que conforman el índice de reproducción social y la adherencia a la profilaxis. Se realizaron pruebas no paramétricas de Kruskal-Wallis y Mann-Whitney, así como el análisis de suma del instrumento utilizado a través de Excel ${ }^{\circledR}$ y del Statistical Package for the Social Sciences ${ }^{\circledR}$. Se respetaron los preceptos éticos. Resultados: Se detectaron 49 usuarios, con una edad media de 34,7 años y predominantemente hombres (95,9\%). Del total, el 83,6\% eran hombres que se relacionaban sexualmente con otros hombres. Las condiciones que se correlacionaron con la adherencia $(\mathrm{p}<0,05)$ fueron el uso anterior de la profilaxis post-exposición y su ingestión continua. Conclusión: Los profesionales de la salud tienen la responsabilidad de establecer el vínculo con el usuario del servicio, especialmente en la primera atención, a fin de contribuir a la planificación de las intervenciones para la adherencia.

\section{DESCRIPTORES}

VIH; Cumplimiento de la Medicación; Profilaxis Posexposición; Enfermería en Salud Pública. 


\section{REFERENCES}

1. Centers for Disease Control and Prevention. About HIV/Aids [Internet]. Atlanta: CDC; 2018 [cited 2019 Jan 14]. Available from: https:// www.cdc.gov/hiv/basics/whatishiv.html

2. United Nations Programme on HIV/Aids. Miles, to go closing gaps breaking barriers righting injustices [Internet]. Geneva: UNAIDS; 2018 [cited 2019 Jan 14]. Available from: http://www.unaids.org/sites/default/files/media_asset/miles-to-go_en.pdf

3. Boletim Epidemiológico HIV/Aids. Brasília: Ministério da Saúde; Secretaria de Vigilância em Saúde [Internet]. 2018 [citado 2019 jan 13];49(53):72. Disponível em: http://www.aids.gov.br/pt-br/pub/2018/boletim-epidemiologico-hivaids-2018

4. Brasil. Ministério da Saúde; Secretaria de Vigilância em Saúde, Departamento de Vigilância, Prevenção e Controle das Infecções Sexualmente Transmissíveis. Protocolo clínico e diretrizes terapêuticas para profilaxia pós-exposição (PEP) de risco para infecção pelo HIV, IST e hepatites virais [Internet]. Brasília; 2018 [citado 2019 jan 15]. Disponível em: http://www.aids.gov.br/pt-br/pub/2015/protocoloclinico-e-diretrizes-terapeuticas-para-profilaxia-pos-exposicao-pep-de-risco

5. Schechter M. Profilaxia pré e pós-exposição: o uso de drogas antirretrovirais para a prevenção da transmissão sexual da infecção pelo HIV Educ Méd Contin [Internet]. 2016 [citado 2019 jan 17];2(4):112-23. Disponível em: http://www.bjid.org.br/en-pdf-X2177511716574480

6. Oldenburg CE, Bärnighausen T, Harling G, Mimiaga MJ, Mayer KH. Adherence to post-exposure prophylaxis for non-forcible sexual exposure to HIV: a systematic review and meta-analysis. Aids Behav. 2014;18(2):217-25. doi: http://dx.doi.org/10.1007/s10461-0130567-0.

7. Krause KH, Lewis-O'Connor A, Berger A, Votto T, Yawetz S, Pallin DJ, et al. Current practice of HIV postexposure prophylaxis treatment for sexual assault patients in an emergency department. Women's Health Issues. 2014;24(4):e407-12. doi: http://dx.doi.org/10.1016/j. whi.2014.04.003

8. Terra MF, Bertolozzi MR. Does directly observed treatment ("DOTS") contribute to tuberculosis treatment compliance? Rev Latino Am Enfermagem. 2008;16(4):659-64. doi: http://dx.doi.org/10.1590/S0104-11692008000400002

9. Bertolozzi MR, Nichiata LYI, Takahashi RF, Ciosak SI, Hino P, Val LF, et. al. The vulnerability and the compliance in collective health. Rev Esc Enferm USP. 2009;43(spec 2):1326-30. doi: https://doi.org/10.1590/S0080-62342009000600031

10. Trape CA, Yonekura T, Soares CB, Lopes IO, Campos CMS, Silva BRB, et al. Contribuição do conceito de classe social nos estudos da epidemiologia crítica. Rev Ciênc Saúde FESGO [Internet]. 2012 [citado 2019 Jan 19];2:152-160. Disponível em: http://www.saps.com. br/sites/estacio/downloads/revista/07_cienciadasaude_2012.1_atual.pdf

11. Remor E, Milner-Moskovics J, Preussler G. Adaptação brasileira do "Cuestionario para la Evaluación de la Adhesión al Tratamiento Antiretroviral. Rev Saúde Pública. 2007;41(5):685-94. doi: http://dx.doi.org/10.1590/S0034-89102006005000043

12. Milinkovic A, Benn P, Arenas-Pinto A, Brima N, Copas A, Clarke A, et al. Randomized controlled trial of the tolerability and completion of maraviroc compared with Kaletra ${ }^{\circledR}$ in combination with Truvada ${ }^{\circledR}$ for HIV post-exposure prophylaxis (MiPEP Trial). J Antimicrob Chemother. 2017;72:1760-8. doi: http://dx.doi.org/10.1093/jac/dkx062.

13. Thomas R, Galanakis C, Vézina S, Longpré D, Boissonnaul M, Huchet E, et al. Adherence to post-exposure prophylaxis (PEP) and incidence of HIV seroconversion in a major North American cohort. Plos One. 2015;11(10):1-10. doi: http://dx.doi.org/10.1371/journal. pone.0142534.

14. Malinverni S, Libois A, Schuster M, De Wit S, Mols P, Gennotte AF. Adherence to HIV post-exposure prophylaxis: A multivariate regression analysis of a 5 years prospective cohort. J Infect. 2018;76:78-85. doi: http://dx.doi.org/10.1016/j.jinf.2017.10.008.

15. Sultan B, Benn P, Waters L. Current perspectives in HIV post-exposure prophylaxis. HIV/Aids. Res Palliat Care. 2014;6:147-58. doi: $10.2147 /$ HIV.S46585

16. Andrade RG, Iriart JAB. Estigma e discriminação: experiências de mulheres HIV positivo nos bairros populares de Maputo, Moçambique. Cad Saúde Pública. 2015;31(3):565-74. doi: https://doi.org/10.1590/0102-311x00019214

17. Harper GM, Lemos D, Hosek SG. Stigma reduction in adolescents and young adults newly diagnosed with HIV: findings from the project accept intervention. Aids Patient Care STDS. 2015;28(10):543-54. doi: http://dx.doi.org/10.1089/apc.2013.0331

18. World Health Organization. Consolidated guidelines on the use of antiretroviral drugs for treating and preventing HIV infection [Internet]. Geneva: WHO; 2016 [cited 2019 Jan 19]. Available from: http://www.who.int/hiv/pub/arv/arv-2016/en/

19. Kerr L, Kendall C, Guimarães MDC, Mota RS, Veras MA, Dourado I, et al. HIV prevalence among men who have sex with men in Brazil: Results of the 2 nd national survey using respondent-driven sampling. Medicine. 2018;97 Suppl 1:S9-S15. doi: http://dx.doi.org/10.1097/ MD.0000000000010573.

20. Izulla P, McKinnon LR, Munyao J, Karanja S, Koima W, Parmeres J, et al. HIV postexposure prophylaxis in an urban population of female sex workers in Nairobi, Kenya. J Acquir Immune Defic Syndr. 2013;62(2):220-5. doi: http://dx.doi.org/10.1097/QAI.0b013e318278ba1b.

21. Said AP, Seidl EMF. Serodiscordance and prevention of HIV: Perceptions of individuals in stable and non-stable relationships. Interface (Botucatu). 2015;19(54):467-78. doi: https://doi.org/10.1590/1807-57622014.0120

22. Rodríguez A, Castel AD, Parish CL, Willis S, Feaster DJ, Kharfen M, et al. HIV medical providers' perceptions of the use of antiretroviral therapy as non-occupational post-exposure prophylaxis (nPEP) in two major metropolitan areas. J Acquir Immune Defic Syndr. 2013;64 Suppl 1:S68-79. doi: http://dx.doi.org/10.1097/QAI.0b013e3182a901a2.

23. Stopa SR, Malta DC, Monteiro CN, Szwarcwald CL, Goldbaum M, Cesar CLG. Acesso e uso de serviços de saúde pela população brasileira, Pesquisa Nacional de Saúde 2013. Rev Saúde Pública. 2017;51 Supl 1:3s. doi: http://dx.doi.org/10.1590/s1518-8787.2017051000074

24. Brasil. Ministério da Saúde; Secretaria de Estado de Saúde de São Paulo, Centro de Referência e Treinamento DST/Aids de São Paulo. Programa Estadual DST/Aids de São Paulo [Internet]. São Paulo; 2009 [citado 2019 jan. 19]. Disponível em: http://www3.crt.saude.sp.gov. br/iec/pe_dst_aids_sp_portugues.pdf

25. Coelho VSP, Szabzon F, Dias MF. Política municipal e acesso a serviços de saúde São Paulo 2001-2012, quando as periferias ganharam mais que o centro. Novos Estudos CEBRAP. 2014;100:139-61. doi: http://dx.doi.org/10.1590/S0101-33002014000300008. 
26. Malinverni S, Libois A, Gennotte AF, Morté C La, Mols P. Prescription of non-occupational post-exposure HIV prophylaxis by emergency physicians: an analysis on accuracy of prescription and compliance. PLoS One. 2016;11(4):e0153021. doi: 10.1371/journal.pone.0153021

27. Scannell M, Kim T, Guthrie B. A meta-analysis of HIV postexposure prophylaxis among sexually assaulted patients in the United States. J Assoc Nurses Aids Care. 29(1):60-9. doi: 10.1016/j.jana.2017.10.004

28. Oz N, Alon D, Stein GY, Turner D. Adherence and characteristics of HIV post-exposure prophylaxis for a population in Tel Aviv of men who have sex with men. Isr Med Assoc J. 2017;19(4):257-61.

29. Tomori C, Risher K, Limaye RJ, Lith LV, Gibbs S, Smelyanskaya M et al. A role for health communication in the continuum of HIV care, treatment, and prevention. J Acquir Immune Defic Syndr. 2014;66 Suppl 3:S306-S310. doi: http://dx.doi.org/10.1097/ QAI.0000000000000239.

30. Isoldi DMR, Carvalho FPB, Simpson CA. Contextual analysis of nursing assistance to a person with HIV/Aids. Rev Pesq Online Cuid Fund. 2017;9(1):273-8. doi: 10.9789/2175-5361.2017

Financial support:

Fundação de Amparo à Pesquisa do Estado de São Paulo, Process n. 2016/20344-4. 